\title{
DOMINANT CATCH OF SEA CUCUMBER IN DATU ISLAND (SCOTT REEF) AUSTRALIA FOR THE INCOME
}

\author{
Ralph Thomas Mahulette ${ }^{1)}$ and Anthony Sisco Panggabean ${ }^{2)}$ \\ ${ }^{1)}$ Researcher at Research Center for Fisheries Management and Conservation, Ancol-Jakarta \\ 2) Researcher at Research Institut for Marine Fisheries, Muara Baru-Jakarta \\ Received August 16-2010; Received in revised form September 30-2010; Accepted November 22-2010
}

\begin{abstract}
Types of sea cucumbers or trepang which have important economic value and consumed were from the genera Holothuria, Stichopodidae, and Thelenota. Sea cucumbers catch by Indonesian fishermen are not only done in Indonesian waters but also to reach the waters of Datu Island (scott reef), which is Box $74 \mathrm{MoU}$ region. The objective of this scientific paper to know the dominat catch of sea cucumber for the income information in Datu Island (scott reef) were catched by Indonesian fishermen with use the traditional fishing method. Such fishing activities had been going on from generation to generation and is done traditionally. To know sea cucumber or trepang fishing waters of the sea cucumber or trepang catches perform the observations which is a collaboration between the Government of Indonesia represented by Australian Ministerial Forum Research and the Australian Government as represented by the Australian Fisheries Management Authority. Observations were carried out from 4-29 September 2008 with the method of interview which includes biology aspects (length and weight measurements), dominant catch, capture aspects, fishing boat, and fishing gear. The results showed that there are 20 species of sea cucumbers or trepang were caught. Most of the fishing boat operated came from Rote Island or Alor and Madura. There were 29 units of fishing boats inventarized. Fishing boat from Rote Island brings crew of 6-8 people and Madurese with crew 11-15 people. Catchment position $14^{\circ} 00^{\prime} .000^{\prime \prime} \mathrm{S}$ and $121^{\circ} 00^{\prime} .000^{\prime \prime} \mathrm{E}$. Fishing gear used were a long rod, short rod, lantern lights, boat, canoe, goggles, spears, landong, and basket traps. Found catches of sea cucumbers or trepang will be processed directly in place.
\end{abstract}

KEYWORDS:

sea cucumbers, traditional, Datu Island, the MoU Box 74

\section{INTRODUCTION}

Sea cucumber is one of fisheries commodity that has good prospects and high economic value, both in domestic and international. Sea cucumber or (trepang) (England), namako (Japanese), and beche-de-mer (France) in the international market is well known by the name teatfish. There are nine species of sea cucumbers that have been in use as a food ingredient. The economically important species is blackfish (Holothuria nobilis), reddish sea cucumber (Holothuria vittensis), marmorata sea cucumber (Holothuria marmorata), dark blackish sea cucumber (Holothuria edulis), snakefish (Holothuria argus), curryfish (Stichopus variegatus), prickly redfish (Stichopus nanas), white teatfish (Holothuria rigida), and sandfish (Holothuria scabra) (Hyman 1955).

The marine resources in MoU 74 Box are managed by the Australian Government. Under the terms of a memorandum of understanding between the Australian and Indonesian governments, continued traditional fishing activity by Indonesian fishers is allowed, principally the sedentary resources such as bechede-mer (trepang) and trochus, but also for fin-fish and reef shark. Eventhough limited catch data collected by surveillance and regulatory authorities, little is known about the catch of the Indionesian fishers or the effects of fishing on the target species. However, an analysis of limited catch data suggested that sedentary species on and around reefs in the MoU 74 Box were probably heavily depleted (Wallner \& McLouglin, 1996). There is an urgent need for stock surveys as well as catch-and-effort data to develop appropriate management plans for the sustainable harvesting of the living marine resources of the area.

The general experience with these fisheries throughout the world, including other areas of Australia such as Torres Strait and the Great Barrier Reef, is that these sedentary marine resources have proved particularly susceptible to overexploitation (Wright \& Hill, 1993). In Torres Strait, where similar species to those in the MoU 74 Box are caught, the fishery has been overexploited for sandfish, the main commercial species taken. Sustainable management of the resources in the MoU 74 Box requires at least this level of information for evaluating the effects of fishing effort on targets stocks and the effectiveness of protected areas (marine reserves). Such knowledge is essential to develop management for the area, especially to given fishing arrangements with Indonesia, and potentially increasing fishing effort (Wallner \& McLouglin, 1996). 
Datu Island (scott reef) is a reef island located at the MoU Box 1974. Besides that there are some Islands, Ashmore Island, Cartier Island, Browse Island, and Seringapatam Reef Island located around the MoU Box 1974. The Ashmore Island is located 450 nautical miles west of Darwin, 330 n.m north of Broome and 60 nautical miles south of Rote Island of Indonesia, Cartier lies approximately 25 n.m miles to the south-east of Ashmore. Ashmore Island and Cartier Island were declared a Common wealth reserve by the Australian Government to protect the area's outstanding and representative marine ecosystem and facilitate scientific.

Datu Island (scott reef) was the fishing area of sea cucumbers where Indonesian fishermen have done for sea cucumbers collecting since traditionally hereditary (traditional fishing) before the MoU Box set in 1974. Indonesian fishers voyaged toward south lern pastof the Indonesian archipelago seeking new sources of trepang (sea cucumber or holothurians), trochus shell, shark fin, and reef fish. All of sea cucumber fishing activity in Datu Island were dominated by Rote Island and Madura Island.

The objective of this scientific paper to know the dominat catch of sea cucumber for the income information in Datu Island (scott reef) were catched by Indonesian fishermen with use the traditional fishing activity.

\section{MATERIALS AND METHODS}

This observation is a joint activity between the Government of Indonesia represented by Australian Ministerial Forum Research and the Australian Government as represented by the Australian Fisheries Management Authority with the location of observation waters Datu Island (scott reef) (Figure 1).

All aspects of the research reported in this document were undertaken at Datu Island (scott reef) on both north and south reefs. Inventory of sea cucumber catch data were done at the Rote and Madura boat by use interviewed method. In general fishers need to gain much greater familiarity with research objectives and methods and the need to collect accurate data. Measuring length and weight were done at the Rotenese and Madurese boat, after measuring the length and weight we cut the stomach to see the stomach contains. The total weight before measuring will be compare after the stomach contains. The benefits of cooperative research with the fishers are several fold. Firstly, the fishers represent a large resource of expert catchers whose fishing effort covers much of the reef area.

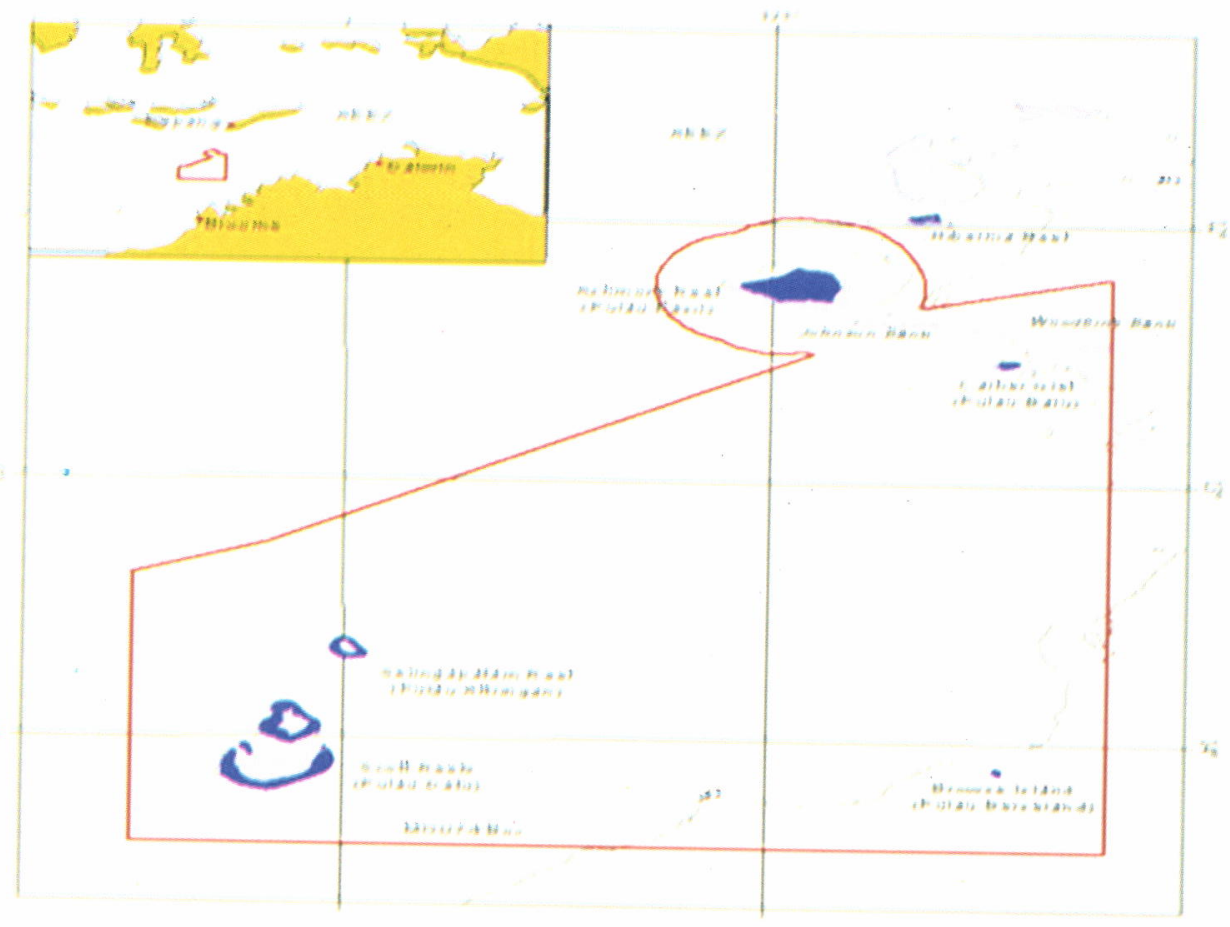

Figure 1. Research location. 
Data collection was conducted during 26 days from the date of September 4-29, 2008. The data collection was done directly on site observations using the method of interview with the respondents (Indonesia fishermen). Biological aspects of data collection (measuring the length and weight), capture aspects, dominat catch fishing boat, and fishing gear.

\section{Fisher Interviews}

Captains and crews of twenty nine perahu were interviewed during the course of the study. About six Rote boat that were at north scott reef during the survey was thought to have left without being interviewed. There were also a number of boat from Tondok and Ra'as at Madura Island that were not interviewed and this may have left boat from that origin under represented in the data. To more clearly can be seen in Appendix 1 Fisher interview datasheet.
Interviews were held in a very friendly and cooperative atmosphere though there was some initial concern about our intentions on several boat which seemed to be resolved quickly. Results of the interviews are found in the following sections and where possible are compared and contrasted with similar interviews from past operations and informal interviews undertaken by Australian fisheries officers.

\section{Origins of Boats and Fishers}

Traditional fishers interviewed during the study came from several different islands and an even greater number of communities as summarised in Table 1. Many of the crews were not from the boats home port and were not the owners of the boat. More than fifty percent of the crews interviewed were from Rote, followed by crews from Alor who are regarded as exceptional divers. Five Madura crews were also interviewed.

Table 1.

Islands from which the crew originated and the respective numbers claiming that Island as home, the home port for the boat and the number of perahu claimed to be from that port are shown

\begin{tabular}{|c|c|c|c|}
\hline Island of crew origin & Claiming that island & Home port claimed & Claiming that port \\
\hline \multirow{4}{*}{ 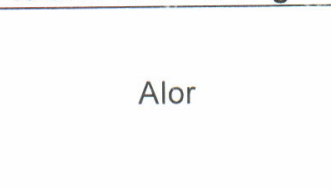 } & \multirow{4}{*}{8} & Ba'a & 1 \\
\hline & & Kalabahi & 2 \\
\hline & & Oelaba & 4 \\
\hline & & Rote & 1 \\
\hline \multirow{4}{*}{ Rote } & \multirow{3}{*}{15} & Oelaba & 7 \\
\hline & & Hundihuk & 6 \\
\hline & & Pepela & 2 \\
\hline & \multirow[b]{2}{*}{5} & Ra'as & 1 \\
\hline Madura & & Tondok & 4 \\
\hline Buton & 1 & Oelaba & 1 \\
\hline Total & 29 & & 29 \\
\hline
\end{tabular}

In total there were $248 \mathrm{crew}$, including captains, on the 29 boat. This equated to between eight and nine men per boat, however the number varied depending on where the crew were from (Table 2).
The boat from Madura were larger than most of the boat from Rotie and more able to carry a larger crew, however there were other important differences discussed later.

Table 2.

Crew numbers by island of origin from perahu interviewed in this survey

\begin{tabular}{cccc}
\hline Island of origin & Crew numbers & Boat & Mean no crew \\
\hline Alor & 63 & 8 & 7.9 \\
Rote & 115 & 15 & 7.7 \\
Madura & 62 & 5 & 12.4 \\
Buton & 8 & 1 & 8.0 \\
\hline Total & $\mathbf{2 4 8}$ & $\mathbf{2 9}$ & $\mathbf{8 . 6}$ \\
\hline
\end{tabular}


Periodic observations of the Indonesian catch and interview surveys completed during earlier snapshot exercises indicated that catches being taken by traditional fishers were still moderately high, despite clear warning signs of depleted stocks in 1998. A significant part of this research program was to ascertain in more detail the species composition of that catch, and weights of each species being taken. Collection of these data was tackled in two ways. First, fishers were interviewed about their catches taken during the period prior to the interview and about the duration of each fishing trip. Second, as a pilot study fishers were invited to participate in a data collection project and were provided with instruction and data sheets. These sheets allowed the fishermen to record catches taken during each 24 hour period or during day and night fishing episodes each day (most did the latter). To simplify this data collection the data sheets used photographs of most species for identification purposes buckets were provided to each boat to make volumetric measurements of their catch by species, or they could count individuals of each species, or do both (most did both) (Prescott et al., 2008).

\section{RESULTS AND DISCUSSION}

\section{Biological Aspects}

Sea cucumber is a cryptic animal. This animal can move very slowly in the reef flat and usually live in the sandy areas, rubble area, and algae area. Most of the economic sea cucumber are live in lagoon area or the outer edge (outer reef) with depths from 5-30 $\mathrm{m}$.

In general, sea cucumbers have a rounded body shape elongated (cylindrical) with oral and aboral line as the axis connecting the anterior and posterior like a cucumber and rough surface of the body due to spicules on the body wall (Hyman, 1955). Usually the base of sea cucumbers will appear on the surface waters at night to find food during the day while the animal was immersed himself in habitats such as sand or rock sidelines to protect themselves from predators. Sea cucumber eating plays an important role as a deposit (deposit feeders) and feed on the suspension (suspension feeder).

Sea cucumbers were stay in relatively calm waters, clear, free from pollution, water temperature between $28-30^{\circ} \mathrm{C}$, salinity between $28-32 \%$, reef flat habitat and can move from one place to another place in the intertidal zone (Azis, 1981).

Based on the type of bottom substrate, the combination of sand, shells and seaweed are most important for the living habitat of the sea cucumber or Holothuridae (Trijoko, 1991).

There are 20 species of sea cucumbers were caught by Indonesian fishermen in Datu Island waters (scott reef), but only a few species have a high price at the market. Observation of length and weight measurements of sea cucumbers were caught by Indonesian fishermen can be seen in (Table 3).

Table 3. Measuring the length and weight of sea cucumbers or trepang

\begin{tabular}{|c|c|c|c|c|c|c|c|}
\hline No. & Type name & English name & $\begin{array}{c}\text { Indonesia } \\
\text { name }\end{array}$ & $\begin{array}{l}\text { Number of } \\
\text { individuals } \\
\text { (n) }\end{array}$ & $\begin{array}{c}\text { Range } \\
\text { length } \\
(\mathrm{mm})\end{array}$ & $\begin{array}{l}\text { Weight range } \\
(\mathbf{g}) \\
\text { with stomach } \\
\text { contents }\end{array}$ & $\begin{array}{c}\text { Weight range }(\mathrm{g}) \\
\text { without the } \\
\text { contents } \\
\text { of the stomach }\end{array}$ \\
\hline 1. & Actinopyga lenacora & Stone fish & Kapok & 4 & $210-270$ & $625-860$ & $620-855$ \\
\hline 2. & Bohadschia argus & Leopard fish & Bintik merah & 7 & $155-290$ & $250-920$ & $195-390$ \\
\hline 3. & Bohadschia marmorata & Leopard fish & Polos & 5 & $110-290$ & $245-820$ & $170-375$ \\
\hline 4. & Bohadschia sp. & Leopard fish & Bintik loreng & 23 & $180-350$ & $355-975$ & $195-520$ \\
\hline 5. & Holothuria atra & Lolyfish & Cerak coklat & 3 & $120-135$ & $20-55$ & $22-40$ \\
\hline 6. & Holothuria coluber & Snake fish & Talengko & 9 & - & $95-245$ & $75-195$ \\
\hline 7. & Holothuria hilla & Holothuria hilla & Coklat merah & 10 & $68-140$ & $8-32$ & 7-32 \\
\hline 8. & Holothuria fuscogilva & White teatfish & Koro susu & 23 & $65-170$ & - & $40-108$ \\
\hline 9. & Holothuria nobilis & Black teatfish & Koro batu & 10 & $90-215$ & - & $46-210$ \\
\hline 10. & Thelenota ananas & Prickly redfish & Nanas & 1 & 540 & 1,650 & 1,600 \\
\hline 11. & Unidentified & & & 95 & $90-170$ & $65-195$ & $56-160$ \\
\hline
\end{tabular}


According to that data in Table 3 were showed that their stomach contains mixed between fine sand, coarse sand and small rubble. It means, a half of the total weight of trepang are sandy and small rocky

\section{Capture Aspects}

The passive nature of sea cucumbers and slow moving very easy to be caught. Activity due to overfishing, as declining populations of sea cucumbers, and even for some types of important economic value tend to be rare, such as sand sea cucumber (Holothuria scabra) and sea cucumber pineapple (Thelenota ananas). The high price of the sea cucumber selling can make a high demand for this species, so can make the catch and trading of sea cucumber was very intensively. Caledonia, Fiji and Indo Pasific countries are most country usually

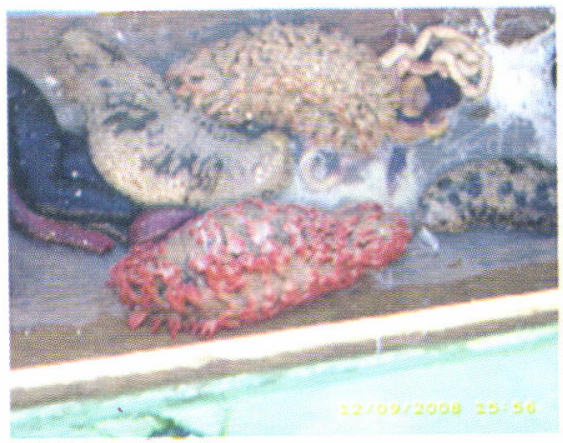

catch and trading sea cucumber since $19^{\text {th }}$ century (Conand, 1980). Similarly in Indonesia sea cucumber fishing has been going on since the Dutch colonial area the region covering most of his cacthment until he came to the archipelago waters of northern Australian regions (northern teritory).

Skewes research in 1999 said, that in the waters of Ashmore Island, Australia had there were estimate of 753 tons of weight $( \pm 219$ tons, $95 \% \mathrm{Cl})$ of sea cucumbers (Holothurians) and animals are commercialized in the area of coral reefs at shallow MoU 74 Box. Abundant species of sea cucumber that is commercialized is Holothuria atra (962.3 and $44.25 \%$ respectively numbers and weight).

Almost all species of sea cucumbers are the waters that are the main target capture (Figure 2).

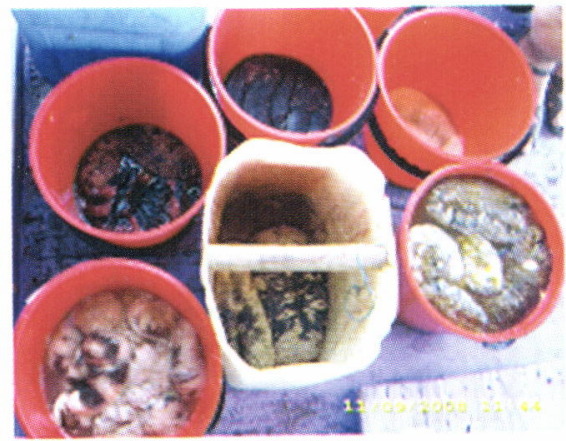

Figure 2

The catch collecting was done in the night when the sea has a low tide in but on the contrary if the sea has a high tide the night fishing activities was done in the day. Fishing activities was depend on the tidal condition of the sea.

Fishing activities was done in once a year for three months (July until September). The main target was the sea cucumber catch and the others catches are molluscs, such as the red lola (Tectus Trochus

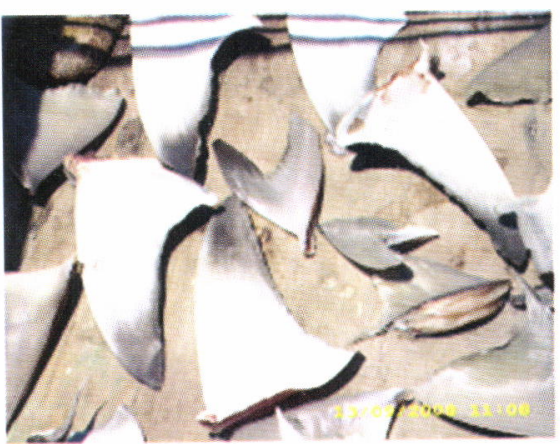

niloticus), white lola (Tectus pyramis), coffee-coffee (Cyprea caputserpentis), bole-bole (Cyprea tigris), bole-bole white (Ovulidae), small red lips (Cassus deer), big red lips (Cassus cornuta), sea snails (Charonia tritonis), and deer horn (Lambis sp.). Besides the sea cucumber, Indonesian fisherman was fishing on other fish, examples sharks fish for take the dorsal fin and reef fishes for the meal or dried (Figure 3).

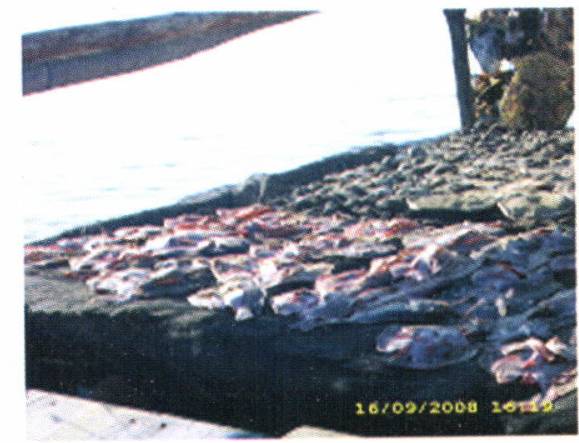

Figure 3. Dorsal fin of sharks and reef fishes. 
Many of the crews interviewed had left their home ports weeks before they were interviewed in this study. Some had left their homes as early as June. However, others left much later and arrived late in the season. The departures from home ports and arrivals at the reef are summarised in Figure 4. The mean voyaging time for the Maduran perahu was 36 days which compared with a mean voyaging time of 20 days for the Rotinese boats.

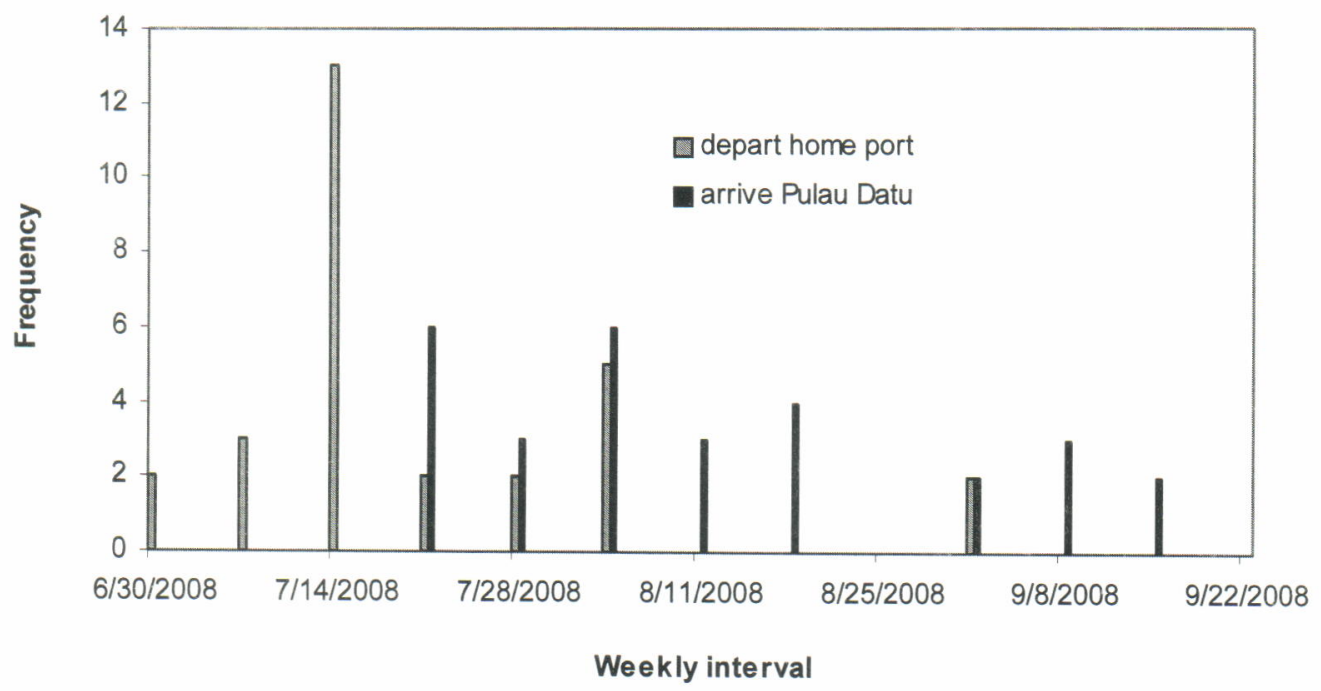

Figure 4. Frequency histogram of weekly departures from the home ports and arrivals at scott reef (Pulau Datu) at a weekly scale.

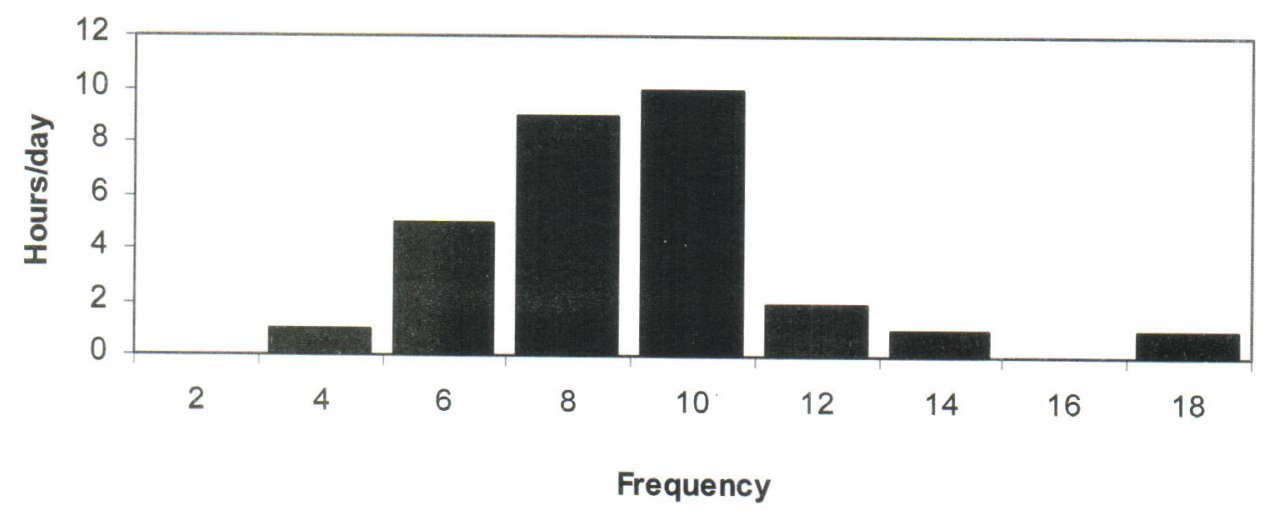

Figure 5. Responses to the numbers of hours fished per day by 29 boat captains.

Different crews expected to spend different lengths of time on the reef, fishing. Boat that arrived earlier generally had an expectation of staying longer and there is a trend of shortened seasons for those who arrived later. Madura boat that arrived late in the season said that they would stay longer than would be expected given the general trend. On average, perahu of Rote origin expected to spend 57 days while those from Madura expected to spend 45 days.

Most boat leave the reef when they are running low on supplies of water and food and at a time that they expect to have favourable winds for the voyage back to Indonesia. Indeed, boats were observed to leave in small groups when the winds became more favourable towards the end of the survey. Each crew generally leaves their boat to fish twice daily. When they do this depends on a number of factors including, most importantly, the tide which also appears to determine whether they will do reef walking or diving. Weather also influences what the crews do, because fishing times are related to tide times.

On average crews indicated that they fished for a total of about 8.4 hours per day however there was a wide range in responses (Figure 5). It seems likely that there were some responses that under and over report hours fished.

There are 2 route taken by Indonesian fisherman. First route was taken by Madurese and the second route was taken by Rotenese. The first route was taken 
from Madura Island sail to Kangean Island, Lombok Island, Larantuka, Kupang, Papela, Pulau Pasir, and the end of the route are Pulau Datu (Datu Island). When they want to go back to Indonesia, they will take another route. The route are they taken for go back to Indonesia start from Pulau Datu (Datu Island) sail to Pulau Pasir, Papela, Lombok, and go direct to Madura Island. The second route were taken from Rote (Papela), Pulau Pasir, and sail direct to Pulau Datu (Datu Island). When they want go back to Indonesia, they will take a same route. Every boat from Madura always use a machine when they left the home port, but after they arrive at Papela they must put of the machine from the boat and leave it at Papela. They must sail from Papela to Pulau datu (Datu Island).

\section{Dominant Catch}

All of species were caught by Indonesian fisherman in Datu Island (scott reef) but not of all have a high price, only a few species had a good price in the market. Deep sea trepang were caught by the Madurese, their target species live in 30-40 m deep on the substrate and the big size trepang. Otherwise, the Rotenese were caught a small trepang which live at the reef flat. All of the species caught by Rotenese and Madurese can describe in the Figure 6.

There are five species were dominant to caught and all of the species have high price. The percentage of dominant catch with will be describe in the Figure 7.

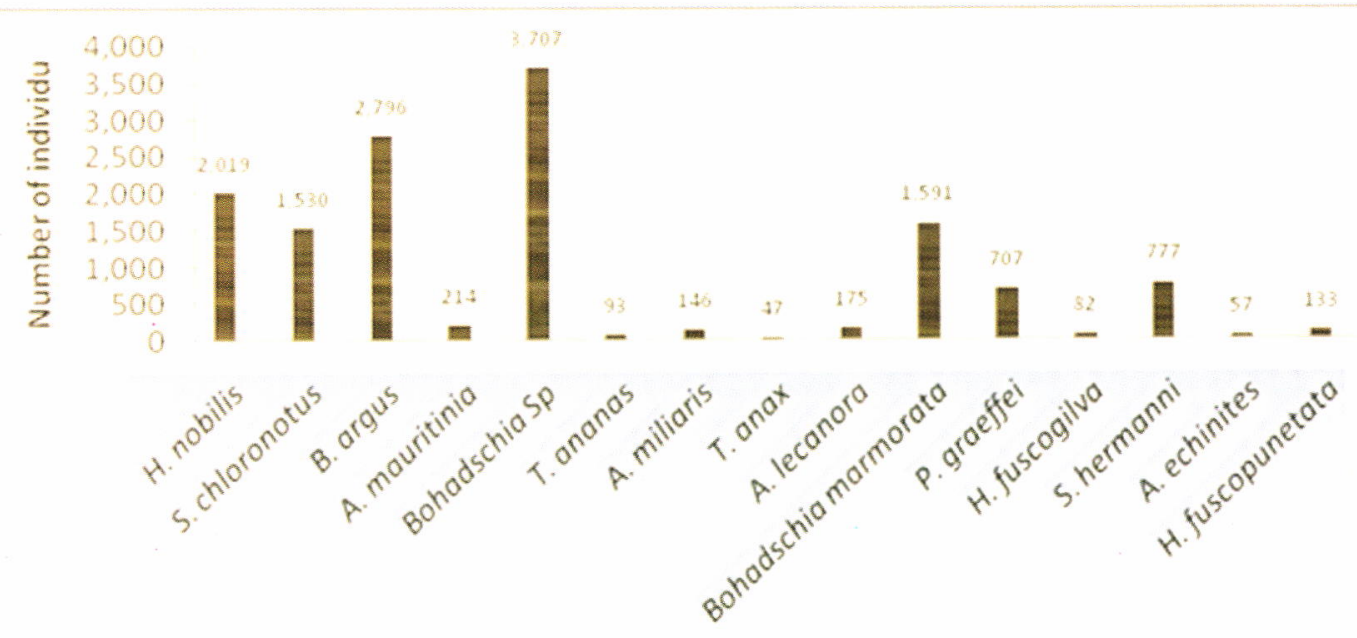

Seacucumber species

Figure 6. All species were caught by Rotenese and Madurese.

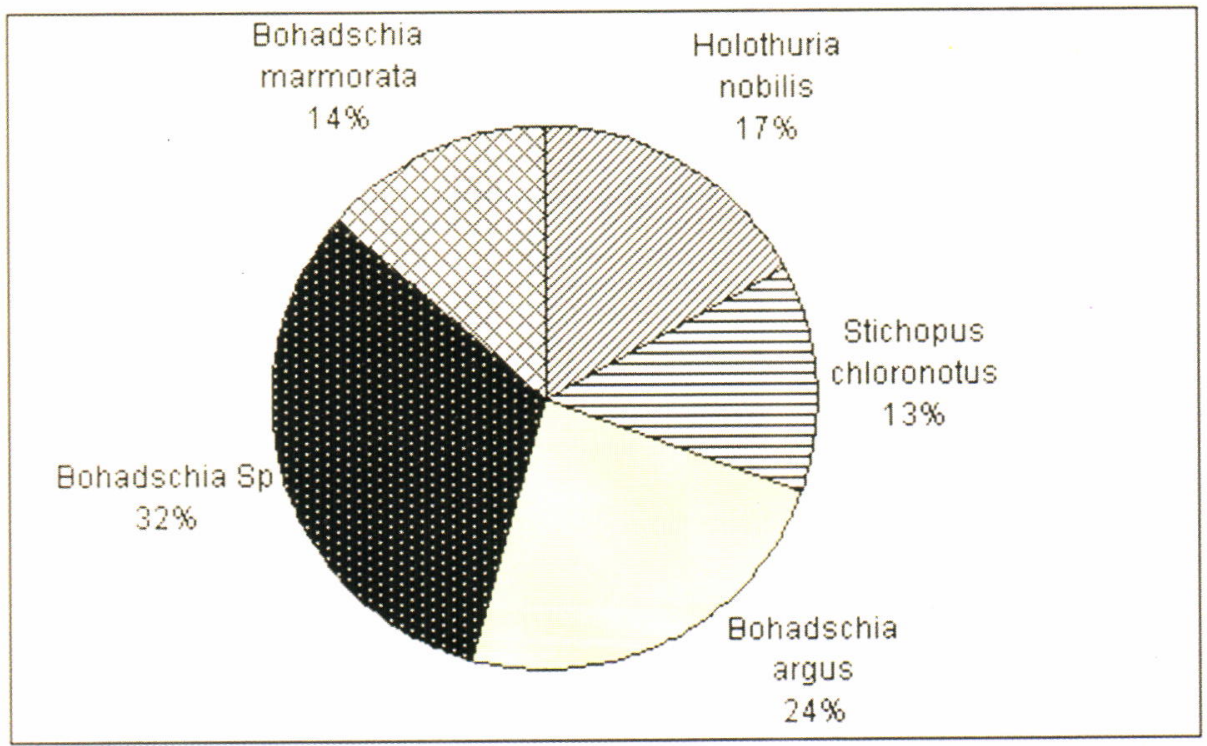

Figure 7. Percentage of dominant catch species. 


\section{Fishing Boats}

Sea cucumber fishing activities in waters that were hereditary activities of their relatives earlier. Catchment area is in position $14^{\circ} 00^{\prime} .000^{\prime \prime} \mathrm{S}$ and $121^{\circ} 00^{\prime} .000^{\prime \prime} \mathrm{E}$.

Under the rules of the Indonesian and Australian fisheries, fishing fleet that can operate in the territory waters fishing for sea cucumbers scott reef a fleet of fishing without the use of machines, not scuba, compressor or respiration dive, fishing gear (purse seine and trawl) or just use the screen and traditional fishing gear (ladung, speargun, knife, matches, baskets, wood, rice, sugar, and salt). At the time of observation data collected on 29 units of fishing fleets operating in the territorial waters of the south and north of scott reef (Table 4).

Table 4.

Fishing boats observed during data collection

\begin{tabular}{|c|c|c|c|c|c|}
\hline No. & Name boat & Name capten & Crews (person) & Origin area & Port of Departures \\
\hline 1. & Bunga Muda & Thomas Lapiweni & 8 & Alor & Ba'a \\
\hline 2. & Putra Sawini & Arfaksad & 8 & Alor & Oelaba \\
\hline 3. & Sinar Indah & Idris Matmin & 6 & Oelaba & Oelaba \\
\hline 4. & Cahaya Mas & Husein & 7 & Rote & Oelaba \\
\hline 5. & Pulau Mas & Markus Lapiweni & 8 & Alor & Kalabahi \\
\hline 6. & Bunga Mas & Sadrak Lapikaana & 6 & Alor & Kalabahi \\
\hline 7. & Mulia Indah & Husni & 8 & Rote & Oelaba \\
\hline 8. & Nuramal 1 & Umar Latief & 8 & Alor & Oelaba \\
\hline 9. & Sejuta Kenangan & Sarimin Abang & 9 & Alor & Oelaba \\
\hline 10. & Getsemani & Wahidin Koli & 7 & Alor & Rote \\
\hline 11. & Padang Arafah & Gafur Kader & 9 & Alor & Oelaba \\
\hline 12. & Berkat 2 & Erwin Tupu & 8 & Rote & Pepela \\
\hline 13. & Alfa Baru & Marcis Giri & 8 & Rote & Hundihuk \\
\hline 14. & Berdikari & Yusuf Donggi & 8 & Rote & Oelaba \\
\hline 15. & Berkat 1 & Melkisedek Pah & 8 & Rote & Hundihuk \\
\hline 16. & Fajar Ilahi & Adrianus Donggi & 8 & Rote & Hundihuk \\
\hline 17. & Cinta Saadia & Anthon & 8 & Hundihuk & Hundihuk \\
\hline 18. & Kartika 2 & Dominggus Dongge & 8 & Oelaba & Oelaba \\
\hline 19. & Kartika 1 & Stefanus Busu & 7 & Rote & Hundihuk \\
\hline 20. & Pelita Hati 1 & Jafar Lapulu & 8 & Buton & Oelaba \\
\hline 21. & Putri Sulung & Kaspadi & 7 & Rote & Oelaba \\
\hline 22. & Permata Hati & Ako Burene & 8 & Rote & Hundihuk \\
\hline 23. & Dinar & Sunahuwei & 13 & Madura & Tondok \\
\hline 24. & Sinar Jaya & Madli & 11 & Madura & Tondok \\
\hline 25. & Harapan Jaya & Mad Saleh & 15 & Madura & Tondok \\
\hline 26. & Irian Jaya & Masari & 12 & Maaura & Tondok \\
\hline 27. & Getsemani 1 & Bastian Balu & 8 & Rote & Oelaba \\
\hline 28. & Nazareth & Okto Boru & 8 & Rote & Pepela \\
\hline 29. & Barakah Jaya 2 & Abdul Ghani & 11 & Madura & Raas \\
\hline
\end{tabular}

Visual observations on the forms of fishing fleets that operate can be distinguished between the fleet that came from the island of Alor and Rote or from Madura (Figure 8 and 9). The number of crew from the fishing fleet Rote Island Alor or less (6-8 persons) compared with those derived from Madura (11-15 people). Armed with courage and an adequate supply of food regardless of the security and safety of Indonesian fishermen are able to travel for miles just to find sea cucumbers are an important economic value of the MoU Box 74 area that has been done by them from generation to generation. 

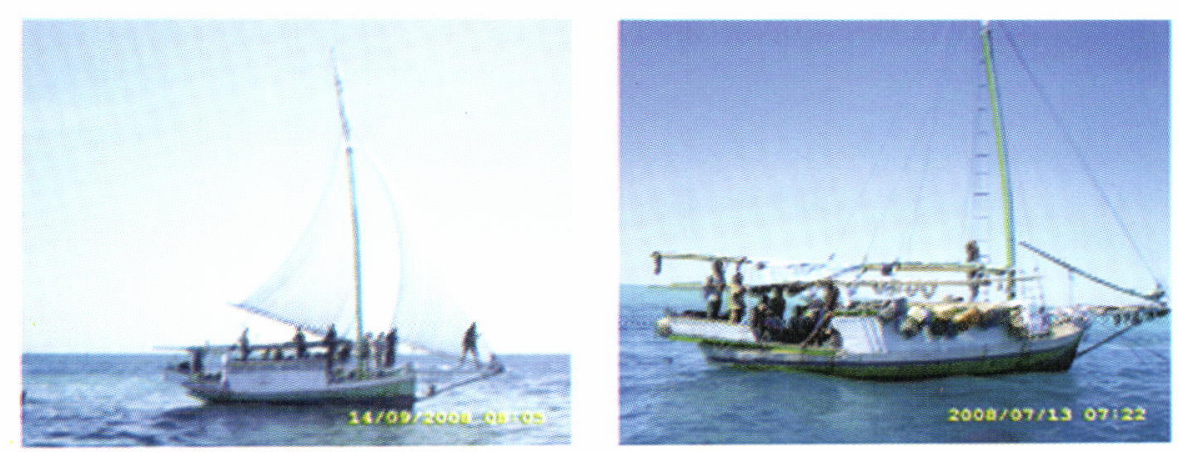

Figure 8. Forms of fishing fleets or from Rote Island Alor
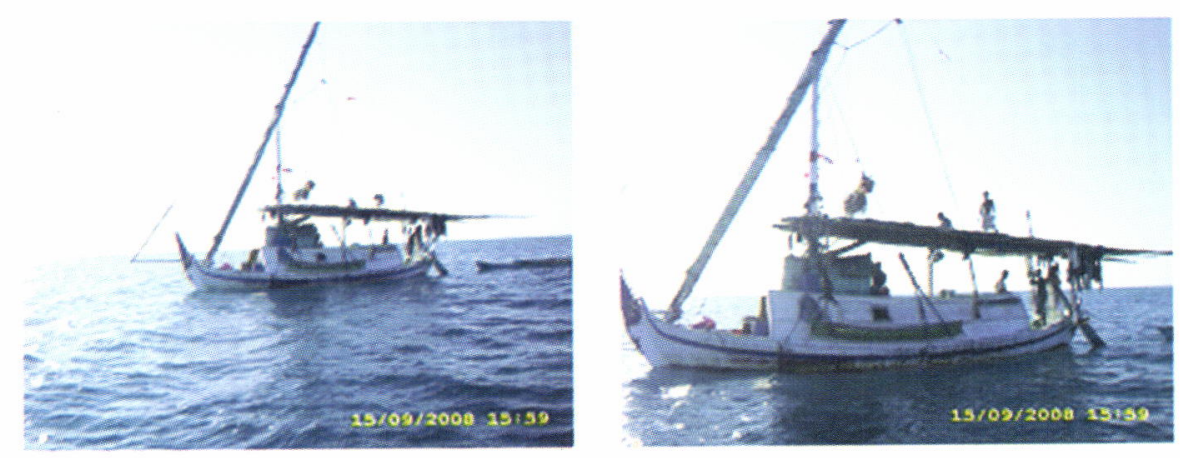

Figure 9. Forms of fishing fleets from Madura.

Almost the entire crew of the fleet that came from Rote Island Alor is dominated by the child or adolescent age (15-20 years) and elderly (above 60 years).

\section{Fishing Gear}

Traditional fishing gear used is own hand made (Table 5). Besides bringing to sea cucumber fishing gear as well as their main target to bring fishing gear to catch fish as the target side. In the cacthment operation usually involved the entire crew will be looking for sea cucumbers in the local stretch of reef and deep.

All of the type fishing gear are very traditional. The Madura always bring a lot of fishing gear when they come to Datu Island (scott reef) because they really want to catch a lot of trepang.

Table 5.

Type of fishing gear in the MoU Box 74

\begin{tabular}{clcc}
\hline \multirow{2}{*}{ No. } & \multicolumn{2}{c}{ Type of equipment to catchment } & \multicolumn{2}{c}{ Total equipment (unit) on origin fleet } \\
\cline { 3 - 4 } & & Alor or Rote & Madura \\
\hline 1. & Long line & $1-8$ & 1 \\
2. & Hand line & $1-10$ & $1-13$ \\
3. & Lanterns or lamp & $1-8$ & $1-12$ \\
4. & Canoas & $1-6$ & $1-11$ \\
5. & Dwing mask & $1-9$ & $1-15$ \\
6. & Spear gun & $1-4$ & $1-5$ \\
7. & Landong & 1 & $1-4$ \\
8. & Baskets & $1-9$ & $1-2$ \\
\hline
\end{tabular}

Fisheries resources are the common property. Property rights over these resources is not clear, so management is open access which means anyone is allowed to manage it (Smith \& Marahudin, 1985). 


\section{CONCLUSIONS}

1. There are 20 species of sea cucumber were caught in Datu Island waters (scott reef) with the traditional fishing gear (lantern lights, boat, canoe, goggles, spears, landing, and basket traps) but not all of them have a high price.

2. The Madurese and Rotenese always every year comes to Datu Island for catch the sea cucumber and they will be stay 2 month (August until September).

\section{ACKNOWLEDGEMENTS}

We both are grateful for the assistance from all levels of Australian Fisheries ManagementAuthority's Foreign Compliance Section, to the Head of Agency for Marine and Fisheries Research to the senior Staff of the Research Centre for Capture Fisheries, and to the Australian Embassy staff in Jakarta without whose assistance the pulling together of this collaborative study in such a short time would not have been possible.

\section{REFERENCES}

Aziz, A. 1981. (in Indonesian). Research status of commercial sea cucumbers in Indonesia. Proceeding of Seminar on Oceanoligy and Marine Enviromental Siences. Lembaga IImu Pengetahuan Indonesia. Jakarta.

Conand, C. C. 1980. Fisheries Resources of Pasific Island Countries Holothurians. FAO Fisheries Technical Papers.
Hyman. 1955. The invertebrates Echinodermata. Vol. IV. McGraw-Hill Book Company. New York.

Prescott, J., R. T. Mahulette, A. S. Panggabean, S. T. kewes, A. Virgona, \& P. Wildekamp. 1998. Report on: Marine Resource Survey South Scott Reef (Pulau Datu), Interview surveys of Indonesian Traditional fishers and a Pilot Cooperative Catch and Effort Data Collection Programme Carried out with Traditional Fishers. The Australia Fisheries Management Authority and Research Center for Fisheries Management and Conservation-Ministry of Maritime Affairs and Fisheries 2009.

Smith, I. R. \& F. Marahudin. 1985. (Eds). Economic Fiheries: From Fisheries management Economic Theory. Foundation Obor Indonesia Gramedia. Jakarta.

Trijoko. 1991. Spread of sea cucumbers (Holothuridae) in Bawean Island. Buletin Mariculture II. 37-40.

Wallner, B. \& K. McLouglin. 1996. Review of Indonesian fishing in the Australian fishing zone. Report for Fisheries Policy Branch. Department of Primary Industries and Energy. Canberra. ACT. 37 pp.

Wright, A. \& L. Hill. 1993. Inshore Marine Resources of the South Pacific: Information for Fishery Development and Management. FFA/USP Press. Fiji. $710 \mathrm{pp}$. 
Appendix 1. Fisher interview datasheet (page two follows on next page)

\begin{tabular}{|c|c|c|c|c|c|c|c|c|}
\hline & Nama Perahu: & & & & & & & \\
\hline Scientifc & & $\begin{array}{l}\text { Bahasa } \\
\text { ndonesia }\end{array}$ & $\begin{array}{l}\text { Common } \\
\text { Erglist } \\
\text { Name }\end{array}$ & catch dry weight & number & Prionity & \begin{tabular}{|l|}
$\mid x$ Soott \\
Reef
\end{tabular} & $\begin{array}{l}\text { \%other } \\
\text { (reef) }\end{array}$ \\
\hline H. whituaei & & Koro 8 atu & $\begin{array}{l}\text { Black } \\
\text { Teattist }\end{array}$ & & & & & \\
\hline H. tuscogilus & & Kora Susu & $\begin{array}{l}\text { Whitse } \\
\text { Teattist }\end{array}$ & & & & & \\
\hline T. ananas & & Nanas & $\begin{array}{l}\text { Prickly } \\
\text { Redfish }\end{array}$ & & & & & \\
\hline A. mauritiana & & Kasut & $\begin{array}{l}\text { Surf } \\
\text { Redfish }\end{array}$ & & & & & \\
\hline A echinites & & & $\begin{array}{l}\text { Deepw ater } \\
\text { Fedfish }\end{array}$ & & & & & \\
\hline A milliaris & & $\begin{array}{l}\text { Obor } \\
\text { (berambut) }\end{array}$ & $\begin{array}{l}\text { Hainy } \\
\text { Black fist }\end{array}$ & & & & & \\
\hline A leonora & & Obor Kapok & Stonefish & & & & & \\
\hline S. chloronatus & & boung & Greentist & & & & & \\
\hline S. horrens & & & $\begin{array}{l}\text { Selenka's } \\
\text { Sea Cuc }\end{array}$ & & & & & \\
\hline H. atra & & Cokolat & Lollyfigh & & & & & \\
\hline H. tuscopundate & & & $\begin{array}{l}\text { Bephant } \\
\text { Trunkfist }\end{array}$ & & & & & \\
\hline H. edulis & & Cera & Pinkish & & & & & \\
\hline H. coluber & & & Snakeish & & & & & \\
\hline 8. argus & & Bintik & Leopardish & & & & & \\
\hline 8. graffei & & & $\begin{array}{l}\text { Black } \\
\text { Spotted }\end{array}$ & & & & & \\
\hline 8. marmorata & & Polos & $\begin{array}{l}\text { Brown } \\
\text { Sandish }\end{array}$ & & & & & \\
\hline T. $\operatorname{anax}$ & $\ldots$ & Downing & Amberish & & & & & \\
\hline
\end{tabular}


